\title{
Nieswoim głosem. Widmo spirytyzmu krąży nad feminizmem
}

Katarzyna Czeczot

TEKSTY DRUGIE 2016, NR 2, S. 343-362

DOI: $10.18318 /$ td.2016.2.18

\section{Magnetyczne zniewolenie}

W Domu o siedmiu szczytach (1851) Nathaniel Hawthorne opisuje, jak prosty cieśla przychodzi do dziedzica starego rodu i hipnotyzuje jego córkę:

Przemówił i Alicja odpowiedziała miękkim, stłumionym, pokornym głosem, skłaniając ku niemu swoją postać niby płomień pochodni pochylony łagodnym powiewem. Skinął dłonią: dumna Alicja powstała z krzesła i ślepo, lecz bez wahania, jakby dążąc do pewnego i nieuniknionego celu, na którym skoncentrowała się cała jej istota, zbliżyła się ku niemu. Oddalił ją ruchem ręki i Alicja cofając się opadła znów na krzesło.

- Moją jest! - powiedział Mateusz Maule. - Moją, prawem silniejszego ducha!1

\section{Katarzyna}

Czeczot - dr, adiunkt w Instytucie Badań Literackich PAN, członkini Pracowni Literatury Romantycznej i Zespołu „Literatura i Gender". Jej zainteresowania naukowe obejmują przedstawienia obłędu w kulturze europejskiej od XIX do XXI wieku, kulturowe konteksty psychiatrii, krytykę feministyczną. Współredaktorka „Encyklopedii Gender" (2014). Kontakt: ka.czeczot@gmail. com

1 N. Hawthorne Dom o Siedmiu Szczytach, przeł. B. Bałutowa, "Czytelnik", Warszawa 1959, s. 202. 
Chwilę potem Maule wyprowadzi dziewczynę z dziwnego stanu, którego współcześni Hawthorne’a nie nazywali hipnozą, lecz określali jako „sen magnetyczny". Władza cieśli nad dziewczyną będzie jednak trwała dalej. Od tej pory Alicja żyje podwójnym życiem; swoim i bezwolnej marionetki, w którą przemienia się, ilekroć Maule jej rozkaże. „Wystarczyło, by [...] siedząc przy swoim skromnym kominku skinął tylko ręką, i gdziekolwiek znajdowała się ta dumna panna [...] - duch jej wychodził spod jej władzy i skłaniał się przed wolą Maule'a"'.

Sformułowana przez Franza Antona Mesmera teoria magnetyzmu zwierzęcego, która we Francji najgoręcej była dyskutowana w ostatnich dekadach XVIII wieku, przyćmiewając swoją sławą nawet wydarzenia rewolucji³, na drugą stronę Atlantyku dotarła stosunkowo późno. Jej „ambasadorem” stał się Charles Poyen St. Sauveur. Z magnetyzmem zetknął się on na studiach medycznych w Paryżu, do Stanów Zjednoczonych przybywa w 1836 roku i niemal natychmiast rusza w trasę z wykładami, którym towarzyszą demonstracje, jak wprowadzać w sen magnetyczny. Pokazy Poyena cieszą się ogromną popularnością i sprawiają, że z mesmeryzmem zaczynają eksperymentować przeciętni Amerykanie. Wśród nich jest krawiec z Poughkeepsie, William Levingston. W 1843 roku Levingston magnetyzuje Andrew Jacksona Davisa, który, doznawszy duchowego objawienia, stworzy na gruncie medycznej doktryny, zrodzonej w klimacie oświecenia, zręby nowej religii - spirytyzmu $u^{4}$.

U Hawthorne'a wyraźne są zarówno ślady nauki Mesmera, jak i wpływy praktyk okultystycznych. Maule, wykonując wzdłuż ciała Alicji podłużne ruchy rąk, stosuje metody zalecane w XVIII-wiecznych poradnikach, ale robi to po to, by - za pośrednictwem dziewczyny - „zajrzeć w świat duchów”. Jednak ani uzdrowicielskie przekierowywanie fluidów, ani komunikacja ze zmarłymi nie budzą u Hawthorne’a takiej ciekawości jak sekretna siła, która Alicję „zmuszała [...] do spełniania groteskowych i fantastycznych rozkazów wbrew jej woli"s; oferowana przez magnetyzm możliwość przejęcia nad innym człowiekiem całkowitej władzy.

2 Tamże, s. 204.

3 Zob. R. Darnton Mesmerism and the End of the Enlightenment in France, Harvard University Press, Cambridge-Massachusetts 1968.

4 Zob. A. Crabtree From Mesmer to Freud: Magnetic Sleep and the Roots of Psychological Healing, Yale University Press, New Haven-London 1993, s. 218-232.

5 N. Hawthorne Dom o Siedmiu Szczytach, s. 204. 
Przytoczona scena wpisuje się w ciąg przedstawień, które, sięgając po popularny motyw wszechwładnego magnetyzera, ilustruje kobiecą bezbronność w obliczu męskiej dominacji. Hawthorne zresztą sam wydobywa płciowy aspekt mesmerycznego eksperymentu: Alicja „przeczuwała instynktem, być może, że jakaś złowroga lub szatańska siła pragnie się wedrzeć do jej duszy i nie cofnęła się przed walką. Tak zatem Alicja przeciwstawiła potęgę kobiety potędze mężczyzny; siły często nierówne - na niekorzyść kobiety"6. Postać demonicznego mężczyzny obdarzonego nadnaturalną mocą, przejmującego władzę nad niewinną dziewczyną powraca w prozie Hawthorne’a. Oprócz Maule'a należą do nich Westervelt, Aylmer, Rappaccini.

Elaine Showalter dowodzi, że obrazy mesmerysty i jego obiektu przynależą do tej samej „ikonograficznej konwencji” co „wampir i jego ofiara, Charcot i jego histeryczka, więzienny lekarz i jego sufrażystka"7 . Na wszystkich wymienionych przez badaczkę obrazach męska władza przejawia się w pozbawianiu kobiety możliwości działania. Zwampiryzowane, zahipnotyzowane, zagłodzone ciało staje się bezwolne i zaczyna niebezpiecznie przypominać trupa. To podobieństwo uruchamia zestaw metafor, które wzmacniają ideologiczny przekaz ukryty w analizowanej przez Showalter ikonograficznej tradycji. Należą do niego: kobieta-lalka (marionetka, kukiełka), kobieta-automat, kobieta-instrument muzyczny, kobieta-naczynie. Metafory te spaja założenie, że kobiece ciało stanowi bierną, bezwolną materię, nad którą zewnętrzna siła może przejąć kontrolę.

Wyobrażenie kobiecego ciała jako instrumentu muzycznego towarzyszy historii hipnozy właściwie od samego początku. Pojawia się już w tajnym raporcie, sporządzonym dla Ludwika XVI, który zaniepokojony pogłoskami o seansach Mesmera chciał dowiedzieć się, czy magnetyzm nie stanowi zagrożenia dla moralności. Autorzy dokumentu, wyjaśniając w nim m.in., dlaczego kobiety wpadają w trans częściej niż mężczyźni, dowodzą, że mają one nie tylko wyobraźnię „żywszą i bardziej pobudliwą niż u mężczyzny", ale również bardziej wyczulone nerwy i delikatniejsze zmysły, które czynią je szczególnie wrażliwymi na dotyk. Upodabnia to kobiece ciało do

6 Tamże, s. 199.

7 E. Showalter The Female Malady: Women, Madness, and English Culture, 1830-1980, Pantheon, New York 1985, s. 207.

8 J.-S. Bailly Rapport secret présenté au ministre et signé par la Commission précédente, Paris 1784. http://franklinpapers.org/franklin/framedVolumes.jsp?vol=42\&page=115 (15.02.15). Kolejne cytaty z tej samej strony. 
instrumentu o „doskonale napiętych i wibrujących unisono” strunach. „Dotykać jakąkolwiek część ich ciała to tak jakby dotykać je wszędzie", jedna struna bowiem wprawia w drganie pozostałe. Na tej samej zasadzie konwulsje jednej kobiety udzielają się drugiej - jest to zjawisko analogiczne do rezonansu.

Hawthorne nie porównuje nigdzie Alicji do instrumentu, w jego powieści jednak ważną rolę odgrywa należący do niej klawikord, który po jej śmierci straszy - wydając z siebie dźwięki jakby pod dotykiem niewidzialnej dłoni. To pudło klawikordu, na którym grają jedynie duchy, staje się powidokiem obrazu ciała, pozbawionego życiowych sił, niezdolnego do stawienia oporu. Showalter słusznie przywołuje postać Charcota - jego postępowanie z histeryczkami przypominało grę na instrumencie. Uciskając odpowiednie miejsca na ciałach zahipnotyzowanych pacjentek, wydobywał z nich przejmujące krzyki, którym towarzyszył zwykle atak konwulsji.

Fantazje o kobiecym ciele jako instrumencie muzycznym kulminują w słynnej powieści George'a du Mauriera Trilby (1894). Książka opowiada o spotkaniu demonicznego pianisty Svengaliego i tytułowej Trilby, młodej Angielki dorabiającej w Paryżu jako modelka. Dziewczyna, obdarzona potężnym głosem, lecz zupełnie pozbawiona słuchu zostaje zahipnotyzowana przez muzyka, który, korzystając z jej podatności, zaczyna ją uczyć śpiewu. Z czasem przejmuje nad nią zupełną kontrolę, Trilby bierze z nim ślub i rozpoczyna karierę wokalną, występując zawsze w transie, z oczami wbitymi w swego męża, dyrygującego orkiestrą. Kiedy pod koniec powieści asystentowi pianisty przyjdzie wyjaśnić zagadkę dziewczyny jej przyjaciołom, powie on: „Było dwie Trilby”. Jedna, która „nie potrafiła wyciągnąć nuty bez fałszu”. I druga - Svengalowska:

Dość mu było powiedzieć „Dors”, a w jednej chwili stawała się jego rzeczą, jego własnością, przelewał w nią swoje myśli, swoją wolę - kazał jej wydobywać z gardła dźwięki niezrównane, czarodziejskie, kazał jej kochać siebie, jakąś sztuczną, dziwną miłością... Było to jakby jego własne uczucie dla niej, odwrócone podszewką na wierzch [...]. Ta Trilby była jakby maszyną śpiewającą - instrumentem, z którego myśmy wydobywali tony - Stradivariusem, fletem ze krwi i kości - głosem, niczym innem, jak tylko głosem, którym właściwie Svengali śpiewał $[\ldots]^{10}$

9 Zob. np. J.-M. Charcot Leçons du mardi à la Salpêtrière. Polyclinique. Course notes by Blin, Charcot, and Colin, Progrès médical/Lecrosnier \& Babé, Paris 1888-1889, s. 276.

10 G.L. Du Maurier Trilby, przeł. E. Żmijewska, M.A. Wizbek, [b.n.w.], Warszawa 1895, s. 276-277. 
U Mauriera porównanie do instrumentu nakłada się na metaforę naczynia, by wyrazić tę samą fantazję - o kobiecie, którą można zapełnić własnymi treściami. Jego powieść stanowi zarazem ładną ilustrację pewnego paradoksu. Fałszując, Trilby jest autentyczna. Przestaje być sobą, gdy zaczyna śpiewać czysto - wówczas przemawia przez nią diaboliczny muzyk.

Spośród przedstawień kobiet poddawanych hipnozie przykuwa uwagę bohaterka Bostończyków Henry'ego Jamesa (1885-1886), Verena Tarrant. W jednym z pierwszych rozdziałów powieści, którego akcja toczy się w salonie panny Birdseye, energicznej abolicjonistki skupiającej wokół siebie osoby z postępowych kręgów miasta, Verena zgłasza chęć przemówienia do zebranych gości, tłumacząc im jednak, że - aby zacząć - potrzebuje pomocy ojca, znanego w mieście mesmerysty. Chwilę potem dziewczyna siada na krześle, a stojący za nią ojciec kładzie na jej głowie ręce: „ - Sza, sza - mamrotał od czasu do czasu. - To przyjdzie, moje drogie dziecko, przyjdzie. Poddaj się mu, niechaj cię wzmocni. Duch się pojawi wedle własnego uznania"11. Najwyraźniej pojawia się, bo wkrótce Verena wstaje i zwraca się do zebranych:

Rozpoczęła nieskładnie, prawie bezgłośnie, jakby mamrotała we śnie. [...] „Porządkuje swoje myśli, zaraz wyjdzie na prostą”, zabrzmiała wypowiedziana ściszonym tonem uwaga mesmerysty. Jego słowa się sprawdziły i po chwili w istocie wyszła, elektryzując publiczność. Posuwała się powoli i z rozmysłem, jakby nasłuchiwała podpowiedzi suflera, łapiąc po kolei zdania podsuwane jej z dużej odległości, której zmierzyć nie sposób. Potem wróciła jej pamięć, albo natchnienie, i znów weszła w rolę. Odgrywała to z niezwykłą prostotą i wdziękiem, po upływie dziesięciu minut nie ulegało wątpliwości, że cała widownia - pani Farrinder, panna Chancellor i niedowiarek z Missisippi - znalazła się pod jej urokiem. ${ }^{\mathbf{1 2}}$

Pamięć czy natchnienie? Sama Verena swoje porywające przemowy komentuje słowami: „to nie ja”, ojciec zaś wyjaśnia je zewnętrzną siłą, która przepływa przez córkę ${ }^{13}$. Wyobrażenie kobiety jako naczynia zostaje zmodyfikowane zgodnie z wykładnią spirytyzmu: tym razem wypełnia je nie 
świadomość magnetyzera, ale duch. Pokazuje to, do jakiego stopnia przedstawienia mediumicznych kobiet wchłonęły wyobrażenia, jakie krążyły na temat pacjentek pogrążonych w magnetycznym śnie. Spirytyści, którzy używali języka elektryczności, by opisać różne pozycje, jakie dana płeć zajmuje względem duchów, mężczyznom przypisywali dodatniość, a kobietom ujemność. „Medium może być mężczyzną lub kobietą - kobietą lub mężczyzną - ale w którymkolwiek wypadku, jego właściwość będzie kobieca - negatywna i bierna"14. W miejsce podatności nerwów, na którą nacisk kładli lekarze, pojawia się podatność na zjawienia duchów.

Ostatnie zdanie zacytowanego fragmentu powieści sygnalizuje jednak ważne odchylenie od dotychczasowych ustaleń. Wzięta we władanie zewnętrznej siły Verena z każdym wypowiadanym zdaniem bierze we władanie swoją publiczność. Rzuca na słuchaczy urok, hipnotyzuje ich. Już samo to odwrócenie relacji władzy między magnetyzerem i jego obiektem jest bardzo zastanawiające, tym bardziej jednak zaskakuje treść wygłoszonej przemowy. Jej tematem jest bowiem emancypacja kobiet. Verena żąda przyznania im praw zrównujących je z mężczyznami, mówi o „wielkim siostrzeństwie kobiet" i wzywa do solidarności.

Odmalowana przez Jamesa scena nie stanowi jednak przekornej gry z konwencją. Określa ją raczej impuls realistyczny. Warto przyjrzeć się jej społeczno-politycznym kontekstom. Pozwolą one zrozumieć owo - osobliwe z dzisiejszej perspektywy - powinowactwo między spirytyzmem i feminizmem.

\section{8}

29 marca w Hydesville, farmie położonej pod miasteczkiem Arcadia w stanie Nowy Jork, w domu Margaret i Johna D. Foxów rozlegają się tajemnicze dźwięki. Jak wspomina Margaret Fox: „Czasami wydawało się, jakby to meble były przesuwane, ale po sprawdzeniu okazywało się, że wszystko jest na swoim miejscu. Dzieci tak bardzo się przestraszyły, że doszłam do wniosku, żeby lepiej spały z nami w pokoju"15. Dzieci, o których wspomina pani Fox,

14 A. Braude Radical Spirits: Spiritualism and Women's Rights in Nineteenth-Century America, Indiana University Press, Bloomington 2001, s. 23.

15 R.B. Davenport The Death-Blow to Spiritualism Being the True Story of the Fox Sisters, as Revealed by Authority of Margaret Fox Kane and Catherine Fox Jencken, G.W. Dillingham Co. Publishers, New York 1888, s. 86. 
to jej córki Margaret i Catherine. „W nocy, gdy stuki dały się słyszeć po raz pierwszy - relacjonuje dalej mieszkanka Hydesville - wszyscy wstaliśmy, zapaliliśmy świecę i przeszukaliśmy dom. Przez cały ten czas hałas trwał i dochodził z tego samego miejsca"16.

31 marca, gdy stuki powtarzają się trzecią noc z rzędu, dwunastoletnia Kathie wykrzykuje „Panie Splitfoot, rób tak jak ja!”, i klaszcze w ręce. W odpowiedzi rozlega się ta sama liczba stuków. Gdy Kathie przestaje klaskać, dźwięki również ustają. Następnie swoich sił próbuje starsza córka, piętnastoletnia Margaret: „A teraz rób tak jak ja!”, i liczba stuków znowu się zgadza. Wówczas pani Fox postanawia przeprowadzić test. Prosi, by podać kolejno wiek każdego z jej dzieci. Rozlegają się serie stuków, z których każda odpowiada liczbie lat jej siedmiorga dzieci. Gdy pani Fox pyta, czy tak precyzyjnych odpowiedzi udziela istota ludzka, następuje cisza. „Czy jesteś duchem? Jeśli tak, zastukaj dwa razy". Ledwo kończy te słowa, dają się słyszeć dwa puknięcia" ${ }^{17}$.

W pierwszych dniach kwietnia przez dom państwa Fox przewijają się setki ludzi, zwabionych historią o tajemniczych stukach. Duch - z którym komunuikacja staje się łatwiejsza za sprawą kodu polegającego na przypisaniu do każdej litery alfabetu określonej liczby - okazuje się zamordowanym domokrążcą, pochowanym w piwnicy. Sąsiedzi postanawiają odkopać zwłoki, jednak w trakcie prac piwnica napełnia się wodą, co uniemożliwia dalsze śledztwo. Foxowie muszą opuścić dom, przenoszą się do syna, Davida. Tajemnicze stuki podążają za dziewczynkami.

W maju Margaret i Kathie przeprowadzają się do domu starszej siostry, Leah, która mieszka w Rochester.

W czerwcu niewielkiej grupie osób prezentują niezwykłe zjawiska. Wśród zaproszonych gości są abolicjoniści, Isaac Post i jego żona, Amy. Do rewelacji sióstr Fox podchodzą oni sceptycznie, jednak „idea duchów wracających na ziemię, żeby powieźć ludzkość ku nowej epoce koresponduje z ich silną wiarą w ludzki postęp i doskonalenie się"18. Siostry organizują jeszcze kilka takich posiedzeń. To wówczas krystalizuje się schemat seansu spirytystycznego, obowiązujący późniejszych wyznawców.

9 lub 10 lipca (dokładna data nie jest znana) w Seneca Falls (około 40 kilometrów na południowy wschód od Hydesville) Jane Hunt podejmuje

16 Tamże, s. 86.

17 Tamże, s. 87-88.

18 D. Chapin Exploring other Worlds: Margaret Fox, Elisha Kent Kane, and the Antebellum Culture of Curiosity, University of Massachusetts Press, Amherst 2004, s. 41. 
u siebie na herbatce Mary Ann M'Clintock, Marthę Coffin Wright, Lucretię Mott i Elizabeth Cady Stanton. Spośród tej piątki jedynie Lucretia nie mieszka w Seneca Falls, Elizabeth zna się już jednak od spotkania w czerwcu 1840 roku podczas światowego zjazdu przeciwników niewolnictwa w Londynie. Elizabeth towarzyszyła mężowi, reprezentującemu, wraz z dużą grupą innych działaczy, Stany Zjednoczone; Mott należała do szczupłego, ośmioosobowego grona kobiecych delegatek. Ich obecność wzbudziła kontrowersje wśród uczestników zjazdu, którzy nie tylko zadecydowali o nieudzieleniu im głosu, ale umieścili je w osobnej przestrzeni, odgraniczonej od głównego hallu specjalną kurtyną tak, by kobiety pozostały również niewidzialne. Elizabeth, do tej pory w niewielkim stopniu zaangażowana w życie polityczne, na widok upokorzonych działaczek wybucha gniewem. Jednocześnie między nią i Lucretią rodzi się przyjaźń, która przetrwa wiele lat. W lipcu 1848 roku przyjaciółki wracają do pomysłu, jaki przyszedł im do głowy w Londynie, by zorganizować zjazd poświęcony prawom kobiet. I nieoczekiwanie dla siebie samych postanawiają zrealizować swój pomysł w najbliższych dniach.

16 lipca do Mary Ann M'Clintock przychodzi Elizabeth Cady Stanton, by przedyskutować szkic tekstu, który ma oddawać główne idee zjazdu. W rozmowie bierze udział również córka Mary Ann, Elizabeth. Siedząc przy mahoniowym stoliku w salonie, kobiety przeglądają różne deklaracje ruchu abolicjonistycznego, pokojowe konwencje, instytucjonalne statuty. W końcu zaczynają czytać Deklarację Niepodległości, w której odkrywają właściwy wzorzec. Modyfikują preambułę i zastępują osiemnaście skarg na króla listą niesprawiedliwości wyrządzanych kobietom przez mężczyzn ${ }^{19}$. Tak powstaje Deklaraja praw i uczuć. Jej druga część składa się z dwunastu rezolucji, które określają cele ruchu kobiecego.

19 lipca temperatura w Seneca Falls wynosi ponad 32 stopnie. Przed wejściem do kaplicy Wesleyan, wybudowanej w 1843 roku przez byłych metodystów, którzy opuścili swoją wspólnotę religijną, gdy ta odmówiła zajęcia zdecydowanego stanowiska w kwestii niewolnictwa, gromadzą się ludzie. Wśród przybyłych są mężczyźni, mimo że pierwszą sesję zapowiedziano jako wyłącznie z udziałem kobiet. Organizatorki decydują się wpuścić mężczyzn, którym nakazują jednak zachować milczenie. O 11.00 rozpoczynają się obrady. Po wstępnych przemowach Elizabeth Cady Stanton odczytuje Deklarację, najpierw w całości, a potem zatrzymując się po każdym akapicie, by

19 S.G. McMillen Seneca Falls and the Origins of the Women's Rights Movement, Oxford University Press, New York 2008, s. 89. 
przedyskutować jego zawartość ze zgromadzonymi i wprowadzić ewentualne zmiany.

20 lipca uczestniczki i uczestnicy zjazdu debatują nad Deklaracją. Podczas podpołudniowej sesji Stanton odczytuje rezolucje i każda z nich jest osobno poddawana głosowaniu. Jako jedyny budzi sprzeciw punkt dziewiąty, zawierający żądanie praw wyborczych. Uczestniczki i uczestnicy zjazdu wysuwają argument, którym, przeczytawszy szkic dokumentu, posłużył się Henry Stanton, ostrzegając żonę, że tym jednym postulatem wystawi na śmieszność pozostałe. Rezolucja przechodzi minimalną większością głosów.

2 sierpnia odbywa się zjazd kobiet w Rochester. Do komitetu organizacyjnego należy m.in. Amy Post, która zdążyła do tej pory zaprzyjaźnić się z siostrami Fox i wprowadzić je do kręgu swoich znajomych z ruchu abolicjonistycznego.

Jesienią zjazdy ruchu kobiecego odbywają się jeszcze w kilku miastach. $\mathrm{Na}$ wszystkich odczytywana jest Deklaracja uczuć. Prasa regularnie już donosi o działaniach ruchu na rzecz praw kobiet.

W listopadzie Leah Fox wpada na pomysł, by młodsze siostry zaczęły występować publicznie. Postowie obiecują jej pomóc i wynająć w Rochester salę na czterysta osób.

Rok 1848 uchodzi zarazem za datę narodzin spirytyzmu i feminizmu. Wydarzenia na farmie Hydesville za przełomowe uznaje sam Andrew Jackson Davis, który widzi w nich ilustrację własnych tez wyłożonych w wydanym rok wcześniej traktacie The Principles of Nature, Her Divine Revelations, and a Voice to Mankind. O zjeździe w Seneca Falls jako początku ruchu na rzecz praw kobiet pisała Elizabeth Stanton, po latach określając go jako „najwspanialsze posunięcie na rzecz ludzkiej wolności odnotowane na kartach historii - żądanie niezależności dla połowy całej rasy"20.

Ann Braude, autorka książki o związkach między spirytyzmem i ruchem na rzecz praw kobiet, proponuje na wiarę $\mathrm{w}$ komunikację $\mathrm{z}$ duchami zmarłych spojrzeć nie tyle jako na rebelię przeciwko śmierci, ile bunt przeciw autorytetom. Spirytyści, przejmując od kwakrów doktrynę wewnętrznego światła, wierzą, że prawo Boga jest wypisane w każdej ludzkiej duszy, i by dociec prawdy, nie ma potrzeby odwoływania się do zewnętrznych autorytetów. Przekonanie, że wszyskie jednostki dysponują w tym samym stopniu dostępem do prawdy, sprawiło, że spirytyzm przez cały wiek XIX przyciągał

Tamże, s. 102. 
społecznych i politycznych radykałów ${ }^{21}$. Przystań znaleźli tu abolicjoniści, socjaliści, a także rzecznicy reformy małżeństwa, praw dzieci, wolności religijnej, wegetarianizmu. Wszyscy spirytyści popierali również prawa kobiet. Była to wówczas jedyna religia, w której kobiety miały status równy mężczyznom w obrębie ideologii, polityki i praktyki.

\section{Ekstaza i emancypacja}

W 1848 roku duch Margaret Fuller unosi się w Seneca Falls. Ona sama jest w podróży po Europie, ale jej wydany trzy lata wcześniej traktat Woman in the Nineteenth Century [Kobieta w dziewiętnastym wieku] zdołał już zdobyć niemały rozgłos. Zdaniem Susan B. Anthony książka ta wywarła większy wpływ na ruch kobiecy w Stanach niż jakakolwiek inna publikacja ${ }^{22}$. Wiele postulatów sformułowanych tam przez Fuller zostało zresztą włączonych do Deklaracji prawi uczuć.

Kobieta w dziewiętnastym wieku idee emancypacyjne splata z magnetyzmem. Fuller zna, rzecz jasna, popularne sądy na temat teorii Mesmera: „Pokaż mi mężczyznę w jednym z twoich magnetycznych stanów, a uwierzę"23. Pisarka w odpowiedzi na ten złośliwy bonmot przyznaje, że kobiety rzeczywiście łatwiej padają ofiarą własnych urojeń. Ale nie byłoby tak - podkreśla - gdyby ich intelekt był rozwijany proporcjonalnie do innych władz. Łatwość, z jaką kobiety dają się często omamić podczas seansów mających im przynieść ulgę w cierpieniach, stanowi dla pisarki kolejny argument przeciw systemowi, który kobiety kształci wyłącznie na towarzyszki i matki dla mężczyzn. „Gdy intelekt $\mathrm{i}$ afekty pozostają w harmonii; gdy przytomność umysłu jest spokojna igłęboka, natchnienie nie pomiesza się z wytworami kapryśnej wyobraźni”24.

Trans jest dla Fuller źródłem poznania i mocy. Pisarka zna ten stan z autopsji - w latach 1837-1845 próbuje magnetycznych kuracji u różnych osób, by wyleczyć bóle głowy i skrzywienie kręgosłupa. Zabiegi nie tylko przynoszą ulgę w cierpieniu. Wywołując łagodny trans, otwierają pisarce drogę do mistycznej iluminacji. Doświadczenie bólu i niepełnosprawność będą miały

\footnotetext{
21 A. Braude Radical Spirits, 57.

22 S.G. McMillen Seneca Falls and the origins of the women's rights movement, s. 78.

23 M. Fuller Woman in the Nineteenth Century and Other Writings, ed. and introd. D. Dickenson, Oxford University Press, Oxford-New York 1994, s. 66.

24 Tamże, s. 68.
} 
jednak dla jej przebiegu ogromne znaczenie. Fuller, dostrzegając w magnetycznym transie możliwość wniknięcia w naturę rzeczywistości, nie utożsamia go z przezwyciężeniem ciała, lecz z włączeniem go w proces poznawczy i zharmonizowaniem z duszą. Jak dowodzi Deborah Manson, to właśnie afirmacja ciała jako rodzaj korekty do mistycyzmu stanowi fundament feministycznego projektu Fuller25.

Większą podatność kobiet na magnetyczny wpływ pisarka traktuje jako cenny dar, ważny składnik kobiecego geniuszu. Ówcześnie często tłamszony za sprawą uprzedzeń i przesądów, z czasem rozbłyśnie i rozleje się po świecie. "Można się po nim spodziewać wszystkiego"26. Christina Zwarg dostrzega w traktacie Fuller wpływy Charles'a Fouriera, który nietypowe stany umysłu uważał za korzystne dla rozwoju społecznych cnót ${ }^{27}$. Naładowane magnetycznie kobiety, pokrewne Jasnowidzącej z Prevorst, „która, jak jej antenatka z Delf, została przebudzona do ekstazy i szaleństwa przez dotyk wawrzynu"28 - stanowią zapowiedź przyszłej epoki, którą poprzedzi społeczna rewolucja.

Rozważania Fuller stanowią ciekawy komentarz do niezwykłego zjawiska, jakie stanowią publiczne wykłady pogrążonych w transie kobiet. Są to spirytystki, które pełnią rolę medium; otrzymując komunikaty od duchów, pośredniczą między ich światem i światem żywych. Ten szczególny status pozwala im złamać prawo zabraniające kobietom zabierać głos na zgromadzeniach wspólnot religijnych. Trzeba tu dodać, że zakaz ten, uzasadniany cytatem z listu do Koryntian („Niech niewiasty na zgromadzeniach milczą, bo nie pozwala się im mówić" (1Kor 15,34-36), w praktyce odnosił się do całej sfery publicznej. Kobietom, które porozumiewają się z duchami, spirytyści jednak chętnie udostępniają mównicę, przekonani, że nic nie może bardziej przekonać sceptyków niż wiadomość z tamtego świata. Przekonanie, że kobiety mają delikatniejsze nerwy i łatwiej nawiązują kontakt z duchami, zaczęło jakby zgodnie z zapowiedzią Fuller - grać na ich korzyść. Otwiera im drogę do religijnego przywództwa. „Mediumizm pozwalał kobietom odrzucić ograniczenia dotyczące społecznej roli kobiet bez kwestionowania akceptowanych

25 D. Manson "The Trance of the Ecstatica": Margaret Fuller, Animal Magnetism, and the Transcendent Female Body, "Literature and Medicine” 2006 vol. 25, no. 2.

Tamże, s. 66. Ch. Zwarg Feminist Conversations: Fuller, Emerson, and the Play of Reading, Cornell University Press, Ithaca 1995. 
idei co do kobiecej natury"29. Lata 50. XIX wieku to wysyp mediumicznych oratorek, które jeżdżą z wykładami po całym kraju, są opisywane w prasie, zdobywają sławę i prestiż.

W książce Braude można znaleźć sylwetki wybranych mówczyń. Najsłynniejsza z nich, obdarzona anielskim wyglądem, Cora Hatch, wystąpiła po raz pierwszy, mając jedenaście lat. W wieku czternastu została na stałe zatrudniona przez Towarzystwo Spirytystyczne w Buffalo. Dwa lata później przeniosła się do Nowego Jorku, skąd regularnie jeździła z wykładami do wszystkich większych miast na Wschodzie i Środkowym Zachodzie Stanów. W prasie, która poświęcała charyzmatycznej mówczyni niemało uwagi, podkreślano, rzecz jasna, jej dziewczęcy i niewinny wygląd, w równym jednak stopniu rozpisywano się o jej talentach oratorskich: dykcji, wymowie, potoczystej frazie. Również treść jej wystąpień budziła aprobatę. Dziennikarz „New York Timesa”, bynajmniej nie spirytysta, jej modlitwę nazwał piękną, teorię pełną głębi, język zaś - elokwentnymº

O ile seanse spirytystyczne odbywające się w domu nastawione były na skontaktowanie się z duchami konkretnych osób, o tyle w publicznych występach mediumistek chodziło raczej o przesłanie z tamtego świata. Lizzie Doten utrzymywała, że trans zapewnia jej „dostęp do mądrości wszystkich zstępujących duchów”. Przypomina zanurzenie się w „Oceanie Prawdy”. Utrata przytomności nie była wcale warunkiem zabrania głosu i sposobem na uwiarygodnienie przekazu spirytystycznych mówczyń. Autor artykułu w „Spiritualist Age” zapewnia, że trans nie jest wcale najlepszym stanem do komunikowania się z duchami. Sytuuje się on wyżej niż stan normalny, ale niżej niż „świadome natchnienie” (conscious state inspiration). Choć komentarze rozżalonych czytelników w odpowiedzi na ten artykuł komplikują obraz, to jednak należy pamiętać, że bardzo wiele spośród występujących mediumistek wyglądało podczas transu tak jak w stanie przytomności. Jedynie Cora Hatch przemawiała z oczami wlepionymi w jeden punkt, a przed zakończeniem występu otrząsała się, jakby się właśnie budziła. Inne kobiety sprawiały wrażenie świadomych. Ann Braude, nie negując nigdzie doświadczenia religijnego spirytystek, zauważa trzeźwo: „Ponieważ w transie dostrzegano środek umożliwiający publiczne zabranie głosu kobietom, które inaczej się do tego nie nadawały, poświadczenie ekstazy stało się k o n w e n c ją używaną

29 A. Braude Radical Spirits..., s. 83.

30 Tamże, s. 95. 
do umocnienia prawa kobiet do wstępowania na trybunę"31. Badaczka przytacza zresztą przypadki oratorek, które przez jakiś czas dawały wykłady w transie, a potem potrafiły to robić w normalnym stanie i wygłaszały mowy na zjazdach świeckich reformatorów.

Zakres tematów poruszanych przez kobiety dające występy mediumiczne był bardzo szeroki i nie ograniczał się bynajmniej do spraw „duchowych”. Hatch, a także Lizzie Doten czy Emma Hardinge, by wymienić tu najbardziej znane nazwiska, zabierały głos w sprawie reformy ubioru, ustawodawstwa dotyczącego małżeństwa, wolnej miłości, a także położenia i praw kobiet. Braude cytuje Lizzie Doten, która w transie daje wykład na temat biblijnej frazy „Nie przystoi kobiecie w zborze mówić”. W jej słowach czuć wściekłość i bunt: „Zaiste nie przystoi kobiecie w zborze mówić i nieprzystojny jest kościół. Niech kobieta wyjdzie z kościoła, a kiedy wyjdzie, niech wraz z nią wyjdzie pastor i cała kongregacja" ${ }^{22}$.

\section{Oddać głos}

Własny głos wydaje się jedną z ważniejszych kategorii w historii ruchów emancypacyjnych. Stanowi on metaforę możliwości wyrażania swoich poglądów, potrzeb, pragnień, również w sferze publicznej. Jest figurą upodmiotowienia, pokrewną widzialności. Jego przenośne znaczenie nie zawsze ruguje znaczenie dosłowne. I tak o narodzinach feminizmu decyduje nałożenie się porządku metaforycznego i literalnego. Zakaz zabierania głosu, jaki nałożono na abolicjonistki podczas zjazdu przeciwników niewolnictwa w Londynie, stał się iskrą zapalną ruchu, którego celem było prawo głosu rozumiane jako prawo wyborcze. Deklaracja uczuć mówi, że mężczyźni egzekwując od kobiet przestrzeganie prawa, muszą dać im możliwość współdecydowania o jego kształcie.

Określenie „własnym głosem”, które posłużyło za tytuł lub jego część ogromnej liczbie feministycznych publikacji, jako hasło streszczające ideę emancypacji wzbudza jednak uzasadnione wątpliwości. W pierwszych dekadach ruchu feministycznego problemy związane z tym terminem rysują się w trzech obszarach.

Pierwszy obejmuje reakcję konserwatywnej części społeczeństwa, która w odpowiedzi na głos kobiecego protestu próbuje na różne sposoby podać go

31 Tamże, s. 89. Wyróżnienie moje - K.Cz.

32 Tamże, s. 93. 
w wątpliwość jako nieautentyczny. Sylvia D. Hoffert swoją książkę o działalności amerykańskich feministek przed wojną secesyjną tytułuje When Hens Crow [Gdy kury pieja]. Frazę tę badaczka zapożycza z artykułu prasowego, którego autor, przekonując, że rzeczniczki praw kobiet zachowują się po męsku, porównuje je do kur udających koguty33. Zarzut „niekobiecości”, kierowany pod adresem aktywistek był w stałym repertuarze przeciwników emancypacji. „Bezpłciowe” - pisała o nich prasa lub określała je jako „hybrydy”34. Prześcigano się w dorzucaniu kolejnych atrybutów do portretu dziwoląga, jakiego uczyniono z feministki. Nie tylko określano je jako nieatrakcyjne i pozbawione ogłady („której oczekuje się po przedstawicielkach płci żeńskiej”35), utrzymywano również, że chodzą w męskich strojach i noszą długie, kosmate brody ${ }^{36}$. Śmiałość, stanowczość, waleczność kobiecych aktywistek widziano jako „nienaturalne” i „nienormalne”. W obrazie piejącej kury, który sugeruje uzurpację kobiet, sięgających po nie swoją broń, odżywa zarazem - na osobliwy sposób - motyw medium - żeńskiego ciała mówiącego samczym głosem. Określona w ten sposób emancypantka okazuje się spokrewniona z Trilby, śpiewającą maszyną sterowaną przez Svengaliego.

Drugi powód, dla którego postulat własnego głosu może wydawać się problematyczny, dotyczy strategii przyjętych przez rzeczniczki praw kobiet w pierwszej fazie ich działalności. Hoffert zwraca uwagę, że zanim wyłonił się ruch sufrażystowski, kobiety mówiły o swoim zaangażowaniu politycznym (np. w abolicjonizm), powołując się na cnoty uznawane za kobiece - zdolność do poświęceń i nieoglądanie się na własny interes ${ }^{37}$. Ten język nie nadawał się do artykulacji celów, jakie stawiał sobie ruch kobiecy. Pierwsze pokolenie feministek, pozbawione wzorców politycznej retoryki i poruszające się w przestrzeni całkowicie zdefiniowanej przez mężczyzn, sięga ostatecznie po ich język, wraz z jego metaforami technicznymi i militarnymi. „Kombinacja metafor i analogii używana przez działaczki na rzecz praw kobiet wyzwoliła kobiety z języka i ograniczeń narzuconych im przez ideologie republikanizmu, domatorstwa i dobroczynności, a także dostarczyła modelu utożsamienia.

33 S.D. Hoffert When Hens Crow: The Women's Rights Movement in Antebellum America, Indiana University Press, Bloomington 1995, s. 101. Zob. również s. 116.

Tamże, s. 77, 100.

Tamże, s. 100.

Tamże, s. 101.

Tamże, s. 48. 
Nie przemieniła ich w mężczyzn. Ale - tak jak zreformowany strój - upodobniła je do mężczyzn"38.

Trzecia kwestia, jaka wyłania się przy rozważaniach o figurze własnego głosu, jest bardziej teoretyczna i dotyczy możliwości wyrażania interesu grupowego.W systemie przedstawicielskim mówić własnym głosem to albo reprezentować swoją klasę społeczną, albo być reprezentowanym przez należącą do niej osobę. Rewersem tak rozumianej emancypacji jest więc nieuchronnie gest wykluczenia. Deklaracja uczuć, uzurpując sobie prawo do bycia głosem kobiet, wyraża wyłącznie interesy białych kobiet z klas wyższych. Własny głos - rozumiany w terminach politycznej reprezentacji - okazuje się fałszywą obietnicą, z definicji niemożliwą do spełnienia. Najlepiej ilustruje to podwójny sens określenia „oddać głos”, które, odnosząc się do praw wyborczych, oznacza zarazem pozbawienie się głosu. Oddając głos na kogoś innego, sama skazuję się na milczenie.

Z tej perspektywy ciekawym kontrapunktem dla pierwszego pokolenia amerykańskich feministek okazują się występujące publicznie mediumistki. Wszystkie one podzielają poglądy rzeczniczek praw kobiet, często głoszą je podczas swoich wykładów. Zarazem kategoria własnego głosu, rozumianego jako środek i cel emancypacji, zupełnie do nich nie pasuje. Oddanie przez nie głosu duchom tylko pozornie jednak jest prostym odwróceniem oddania głosu w wyborach. W rzeczywistości stanowi karykaturę politycznej reprezentacji i przekroczenie jej ciasnych ram.

Choć mówczynie występujące w transie adaptują metafory pochodzące z patriarchalnego słownika, określając się w terminach "biernego wehikułu” (od którego blisko już do naczynia), instrumentu, to jednak nie odbiera im to szansy na rolę religijnych przywódczyń. Autorytet duchów nie umniejsza ich autorytetu jako oratorek. Pisarz Nathaniel Parker Willis, podchodząc do spirytystycznej doktryny z dużym dystansem, następująco podsumował występ Cory Hatch: „Bez względu na to, czy wypowiada ona myśli swoje, czy innych duchów, jej elokwencja jest tak nadnaturalna, że najbardziej chwiejna wiara nie mogłaby żądać więcej"39. Spirytystyczne oratorki, sięgając po męskie przywileje, nie narażają się na zarzut niekobiecości. Choć widok

Tamże, s. 72. Zreformowany strój to kostium zaprojektowany przez Ann Bloomer, składający się z tureckich spodni noszonych pod spódnicą. Przez jakiś czas był bardzo popularny wśród emancypantek, większość z nich porzuciła go jednak, licząc, że tradycyjny strój przyda im wiarygodności. 
publicznie przemawiającej kobiety dla wielu osób musiał być szokujący, odnotowywano jednak ten fakt z wyrazami podziwu bądź pokornego uznania. Korespondent „Banner of Light” w transowych występach mediumistek widział niezbity dowód na prawdziwość doktryny spirytyzmu, ponieważ wysłuchane przez niego kobiety „nigdy nie byłyby w stanie i nawet nie próbowałyby, z tego co wiemy, dać takich wykładów w normalnym stanie"40.

Wbrew temu, co mogłyby sugerować inne przypadki mediumizmu, spirytystki, o których pisze Braude, mówią nie swoim głosem jedynie w przenośni. Świadczą o tym relacje współczesnych, które podkreślają ich oratorskie zdolności. Charakteryzując zachowanie Cory Hatch, Willis wymienia „rozważne i opanowane ruchy, spokojny i głęboki głos, oczy i dłonie - w żadnym razie nerwowe" ${ }^{\text {"41 }}$. Użyte przez niego słowo "self-possessed" stanowiące przeciwieństwo „possession”, a więc opętania, pozwala wysnuć wniosek, że Hatch, podobnie jak inne pogrążone w transie mówczynie, stając się instrumentem w rękach duchów, zarazem znakomicie panują nad instrumentem, jakim jest ich własny głos. Zyskując kontrolę nad głosem rozumianym fizykalnie i zarazem rezygnując z mówienia we własnym imieniu, spirytystki znów sytuują się na przeciwległym biegunie do sufrażystek, którym publiczne wystąpienia sprawiają wówczas wiele trudności ${ }^{42}$. W Seneca Falls, kiedy debatowano nad kwestią praw wyborczych, obradom przewodniczyli mężczyźni, gdyż organizatorki nie wyobrażały sobie, że w sytuacji mieszanej widowni mogłaby to robić kobieta ${ }^{43}$. Ich kłopoty z publicznym zabieraniem głosu najlepiej obrazuje anegdota przytoczona przez Braude. Podczas jednego ze zjazdów Susan B. Anthony wysunęła wniosek, aby kobiety, które nie potrafią mówić w sposób słyszalny dla widowni, przekazały swoje wystapienia do przeczytania innym osobom. Postawienie kobietom wymogu mówienia donośnym głosem okazuje się kontrowersyjne w oczach samych uczestniczek zjazdu. Paulina Wright Davis sprzeciwiła się propozycji Anthony, argumentując: „damy nie przyjechały tu, by wydawać piski; przyjechały, by zachowywać się jak damy i mówić jak damy"44. To znaczy - cicho. Anthony, jak wiadomo z pozostawionych przez

40

Tamże, s. 85 .

Tamże, s. 94.

Zob. opis publicznego wystąpienia Abby Kelley w M. Fuller Woman in the Nineteenth Century and OtherWritings, s. 72.

3 S.G. McMillen Seneca Falls and the Origins of the Women's Rights Movement, s. 92

A. Braude Radical Spirits..., s. 97. 
nią listów, przez lata dręczyła niepewność co do własnych oratorskich umiejętności. Gdy w 1855 roku zwierza się Elizabeth Cady Stanton z lęku, jakim napawają ją publiczne wystąpienia, z zazdrością wyraża się o popularnych już wtedy spirytystkach, dających wykłady: „Gdyby tylko duchy uczyniły mnie medium i włożyły mi w usta właściwe rzeczy"45.

Spirytyzm nie tylko „stał się jednym z większych, jeśli nie największym wehikułem propagowania praw kobiet w Ameryce w połowie XIX wieku"46. Ruch ten miał również ogromny udział w zwiększeniu widzialności kobiet zabierających głos publicznie. Zważywszy liczebność jego wyznawców i sympatyków ${ }^{47}$, a także powszechną ciekawość, jaką budził, poważnie zachwiał on przekonaniem, że kobiety nie nadają się do pełnienia funkcji publicznych. Znaczenie mediumizmu dla ruchu emancypacyjnego potrafiły docenić same feministki. Kiedy w 1871 roku na krajowym zjeździe Paulina Wright Davis dokonywała podsumowania kampanii na rzecz praw kobiet, pośród ważnych dla niej postaci wymieniła tylko jedno nazwisko osoby niezwiązanej formalnie z ruchem i bezpośrednio z nim niekojarzonej. Była to Cora Hatch, która przemawiała do większej widowni częściej niż jakakolwiek inna kobieta ${ }^{48}$. Mówienie nie swoim głosem okazuje się - z perspektywy czasu - genialną strategią polityczną. Jej skuteczność we wprowadzaniu kobiet do sfery publicznej czyni spirytyzm częścią historii feminizmu.

Moment zazębiania się tych dwóch ruchów zostaje uchwycony w Bostończykach Jamesa, w których wiele sytuacji odsyła do zdarzeń rzeczywistych. Za pierwowzór postaci Vereny uznaje się często Corę Hatch ${ }^{49}$. Sara de Saussure Davis wysuwa przypuszczenie, że równie duży wpływ na konstruowanie tej bohaterki mogła wywrzeć postać Anny Dickinson, charyzmatycznej mówczyni, której talenty usiłowała pozyskać dla ruchu kobiecego Susan B. Anthony, stając się na jakiś czas jej sponsorką i mentorką ${ }^{50}$. Biografia Dickinson

Tamże, s. 97.

Tamże, s. 57.

Ich liczba w drugiej połowie XIX wieku jest trudna do ustalenia ze względu na antyinstytucjonalny charakter ruchu. Mogła wynosić od kilkuset tysięcy do jedenastu milionów. A. Braude Radical Spirits..., S. 25.

Tamże, s. 96.

Zob. H. Kerr Mediums, and Spirit-rappers, and Roaring Radicals; Spiritualism in American Literature, 1850-1900, University of Illinois Press, Urbana 1972, s. 90-222.

S. de Saussure Davis Feminist Sources in The Bostonians, "American Literature" 1979 vol. 50, no. 4 . 
dostarczałaby również wzorca dla historii powieściowego trójkąta, który tworzą Verena, Olive Chancellor i Basil Ransom. Konflikt, w jaki Anthony popadła, walcząc o względy Dickinson, ze swoim przyjacielem, działaczem abolicjonistycznym, Wendellem Phillipsem, w Bostończykach zyskuje jednak zabarwienie polityczne. Oddana sprawie ruchu kobiecego Olive ściera się z konserwatywnym południowcem. Podczas gdy ona marzy o karierze oratorskiej dla Vereny, Mississipczyk chce ją po prostu poślubić i trzymać z dala od wszelkich radykałów. Polityczne zaangażowanie dziewczyny Ransom komentuje, sięgając po odwieczne prawdy mizoginów: nie wierzy, „aby myśli panny Tarrant były z gruntu jej własnymi myślami"51. Przekonany, że to ludzie pokroju mesmerysty „namącili [jej] w głowie”, widzi w Verenie „wzruszającą, naiwną ofiarę, nieświadomą zgubnych sił, które ją pchały do upadku"52.

Pojedynek Olive z Basilem do pewnego stopnia powiela schemat walki o duszę. Ponieważ jednak to nie Szatan i Bóg stoją w nim po przeciwległych stronach, lecz zwykli ludzie, James opisuje ich zabiegi językiem magnetyzmu. Niechętna wszelkim irracjonalnym wierzeniom Olive, która na początku chce przede wszystkim odciąć Verenę od ojca, udowodnić, że potrafi ona występować bez pomocy magnetyzera, czerpiąc siłę z wrodzonego talentu, wkrótce zaczyna zdradzać się z tym, że również myśli o dziewczynie jako naczyniu, wehikule. Biorąc ją pod swoją opiekę, kształcąc i układając wspólnie z nią treść wystąpień, wyznaje Verenie: „Chciałabym móc powiedzieć, że jesteś moim kształtem... moją powłoką"53. Ransom sięga do tego samego zestawu metafor, porównuje dziewczynę do dmuchanej figurki, marionetki ${ }^{54}$. W jego pojedynku z Olive celem jest zdobycie kontroli nad Vereną, środkiem - m.in. wzrok wpijany w ofiarę. James opisuje spojrzenie, którym „Olive przejęła Verenę na własność" ${ }^{55}$, a także rażącą siłę oczu Ransoma, przed którą ugina się dziewczyna ${ }^{56}$. Kluczowe terminy pojawiające się w powieści na określenie tej władzy - „wpływ” i „natchnienie” - również zostały zaczerpnięte z teorii magnetyzmu i są dobrze osadzone w zestawie powiązanych z nią wyobrażeń i fantazji. Wyrażając ideę napełniania pustego zbiornika - płynem (angielskie

51

52

53

H. James Bostończycy, s. 277.

Tamże, s. 314.

Tamże, s. 199.

Tamże, s. 426.

Tamże, s. 103.

Tamże, s. 427. 
influence pochodzi od łacińskiego influere - wpływać, wlewać się) lub powietrzem (inspiration ma źródłosłów związany z oddychaniem) - stanowią inny wariant „zewnętrznej siły”, na którą powoływał się Tarrant.

Dla wymowy Bostończyków zasadnicze wydaje się jednak, że przepływ tej siły, płynu czy powietrza odbywa się też w odwrotnym kierunku, że Verena również wywiera wpływ i daje natchnienie. Pozwala to dostrzec w powieści oprócz historii o perypetiach miłosnych, dziejów zazdrości i rywalizacji - opowieść o spotkaniu sufrażystki i spirytystki, przedstawicielek dwóch ważnych ruchów, które w ówczesnych Stanach wyznaczały miejsce niezależnych i utalentowanych kobiet. Z tej perspektywy relacja między Olive i Veraną w niczym nie przypomina związku Svengaliego i Trilby. Polega raczej na intensywnej wymianie, w której wzajemne wpływy się równoważą. Zakończenia powieści - ucieczki Vereny z Basilem tuż przed jej planowanym występem w Music Hallu - nie sposób podsumować jako przegranej Olive. Ostatnie zdania kreślą obraz tego, jak Olive w zastępstwie Vereny wchodzi na scenę i staje naprzeciw zniecierpliwionej długim wyczekiwaniem publiczności. „Cokolwiek im powiedziała [...], wyglądało na to, że nie cisną w nią

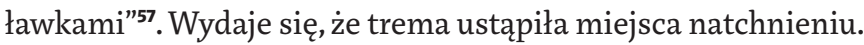

Biografie mediumicznych oratorek nie tylko stawiają na nowo pytanie o relację między feminizmem i religią, dowodząc, że - wbrew popularnym sądom - nie są to ruchy z definicji nawzajem się zwalczające, ale również dostarczają mocnych argumentów przeciwko tezie o oświeceniowych korzeniach ruchu sufrażystowskiego. Ujawniają, że samoświadomy i autonomiczny podmiot emancypacji dojrzewa w cieniu podmiotowości ekstatycznej, nawiedzonej. Oddanie głosu duchom, które deklarują feministki-spirytystki, można z dzisiejszej perspektywy traktować jako wyzwanie rzucone polityce opartej na przeciwstawieniu jednostki i wspólnoty, zarys projektu transindywidualnego.

\section{7}

6 listopada parlament stanu Nowy Jork decyduje o przyznaniu kobietom praw wyborczych. Głosowanie w tej sprawie odbyło się dwa lata wcześniej; żądania sufrażystek zostały wówczas odrzucone zdecydowaną większością głosów. Od tego czasu aktywistki ruchu na rzecz praw kobiet regularnie urządzały manifestacje i pikiety. Wraz z przystąpieniem Stanów Zjednoczonych 
do I wojny światowej ściągnęły na siebie głosy jeszcze większego oburzenia. Uczestniczki protestów były wielokrotnie aresztowane i więzione. Zarzucano im skrajny egoizm, brak patriotyzmu i szacunku dla ofiar czynionych na froncie przez mężczyzn.

3 listopada, trzy dni przed decydującym głosowaniem, „New York Times” publikuje artykuł wstępny będący zjadliwą relacją z kolejnej pikiety, jaką sufrażystki urządzają przed Białym Domem. Artykuł zaczyna się ironicznym pytaniem, ,jaki duch objawił się, by podszeptywać kobietom te prośby o głosowanie?".

\section{Abstract}

\section{Katarzyna Czeczot}

THE INSTITUTE OF LITERARY RESEARCH OF THE POLISH ACADEMY OF SCIENCES

With a Strange Voice: The Spectre of Spiritism is Haunting Feminism

This article discusses nineteenth-century spiritism and its role in forming ideas about women, their bodies, social functions and place in culture. Czeczot begins by demonstrating that to a certain extent, representations of mediumistic women perpetuated the iconographic tradition that had begun with images of magnetic séances, which, by highlighting the power of the magnetizer, helped strengthen notions of women's bodies as a passive matter. In the context of these conventional beliefs, women stand out who claim to be in communication with the spirits and who, beginning in the 1850s, appear publicly to deliver speeches in a trance. Czeczot explores their significance for the women's emancipation movement that was emerging at the time, and positions them as a point of departure to problematize the concept of one's own voice.

\section{Keywords}

feminism, spiritism, magnetism, own voice 